\title{
Alpha-glucosidase inhibitory activity of some brown seaweeds collected in Nha Trang bay, Khanh Hoa province
}

\author{
Han T. Nguyen $^{1 *}$, Yen T. P. Nguyen ${ }^{2,3}$, \& Duong T. H. Ngo ${ }^{2}$ \\ ${ }^{1}$ Faculty of Food Technology, Nha Trang University, Nha Trang, Vietnam \\ ${ }^{2}$ Insitute of Biotechnology and Environment, Nha Trang University, Nha Trang, Vietnam \\ ${ }^{3}$ Quality Management Department of Agriculture, Forestry and Fisheries, Lam Dong, Vietnam
}

\begin{abstract}
ARTICLE INFO
Research Paper

Received: December 16, 2019

Revised: January 28, 2020

Accepted: February 25, 2020
\end{abstract}

\section{Keywords}

$\alpha$-glucosidase inhibitor

Brown seaweeds

Diabetic

Extraction conditions

Sargassum mcclurei

${ }^{*}$ Corresponding author

Nguyen The Han

Email: hannt@ntu.edu.vn

\section{ABSTRACT}

Diabetes has become a global problem in recent years. Inhibition of $\alpha$-glucosidase is one of the effective approaches to control the postprandial blood gluccose and thereby mananging diabetes. This study evaluated inhibitory activity of seven brown seaweed extracts (Colpomenia sinuosa, Padina australis, Sargassum aquifolium, Sargassum mcclurei, Sargassum duplicatum, Sargassum polycystum và Sargassum swartzi) against $\alpha$-glucosidase. The results indicated that all seaweed extracts inhibited enzyme activity with the $\mathrm{IC}_{50}$ values ranging from 154.27 to $426.27 \mu \mathrm{g} / \mathrm{mL}$. The seaweed Sargassum mcclurei showed the highest $\alpha$-glucosidase inhibitory activity. The effects of extraction conditions and extraction solvent fractions on $\alpha$-glucosidase inhibitory activity of Sargassum mcclurei were investigated. The suitable extraction conditions were found to be the solid to liquid ratio $(\mathrm{g} / \mathrm{mL})$ of $1 / 40$, the extraction time of $60 \mathrm{~min}$ and the extraction temperature of $60^{\circ} \mathrm{C}$. The ethyl acetate extracted fraction showed the highest $\alpha$-glucosidase inhibitory activity compared with other fractions.

Cited as: Nguyen, H. T., Nguyen, Y. T. P., \& Ngo, D. T. H. (2020). Alpha-glucosidase inhibitory activity of some brown seaweeds collected in Nha Trang bay, Khanh Hoa province. The Journal of Agriculture and Development 19(2), 90-98. 


\title{
Hoạt tính ức chế enzyme alpha-glucosidase của một số loài rong nâu thu mẫu ở Vịnh Nha Trang, tỉnh Khánh Hòa
}

\author{
Nguyễn Thế Hân ${ }^{1 *}$, Nguyễn Thị Phương Yến ${ }^{2,3}$ \& Ngô Thị Hoài Dương ${ }^{2}$ \\ ${ }^{1}$ Khoa Công Nghệ Thực Phẩm, Trường Đại Học Nha Trang, TP. Nha Trang \\ ${ }^{2}$ Viện Công Nghệ Sinh Học và Môi Trường, Trường Đại Học Nha Trang, TP. Nha Trang \\ ${ }^{3}$ Chi Cục Quản Lý Chất Lượng Nông Lâm Sản và Thủy Sản, Tỉnh Lâm Đồng
}

\section{THÔNG TIN BÀI BÁO \\ Bài báo khoa học \\ Ngày nhận: 16/12/2019 \\ Ngày chỉnh sửa: 28/01/2020 \\ Ngày chấp nhận: 25/02/2020 \\ Từ khóa}

Bệnh đái tháo đường

Chất ức chế $\alpha$-glucosidase

Điều kiện chiết

Rong nâu

Sargassum mcclurei

*Tác giả liên hệ

Nguyễn Thế Hân

Email: hannt@ntu.edu.vn

\section{TÓM TẮT}

Trong những năm gần đây, đái tháo đường đã trở thành vấn đề lớn của toàn cầu. Một trong những cách hiệu quả để kiểm soát bệnh đái tháo đường là ức chế hoạt động của enzyme $\alpha$-glucosidase. Nghiên cứu này đánh giá hoạt tính ức chế enzyme $\alpha$-glucosidase của dịch chiết từ 7 loài rong nâu (Colpomenia sinuosa, Padina australis, Sargassum aquifolium, Sargassum mcclurei, Sargassum duplicatum, Sargassum polycystum và Sargassum swartzi). Kết quả nghiên cứu cho thấy tất cả các mẫu rong nghiên cứu đều có hoạt tính ức chế enzyme $\alpha$-glucosidase, với giá trị $\mathrm{IC}_{50}$ dao động từ 154,27 đến 426,27 $\mu \mathrm{g} / \mathrm{mL}$. Dịch chiết của rong Sargassum mcclurei có hoạt tính ức chế enzyme cao nhất. Ảnh hưởng của điều kiện chiết và phân đoạn dung môi chiết đến hoạt tính ức chế enzyme $\alpha$-glucosidase của rong Sargassum mcclurei được nghiên cứu. Điều kiện chiết thích hợp được xác định như sau: tỷ lệ nguyên liệu/dung môi chiết $(\mathrm{g} / \mathrm{mL})$ là $1 / 40$, thời gian chiết là 60 phút, nhiệt độ chiết là $60^{\circ} \mathrm{C}$. Trong các phân đoạn dung môi chiết, phân đoạn dịch chiết ethyl acetate có hoạt tính ức chế enzyme mạnh nhất.

\section{1. Đặt Vấn Đề}

Đái tháo đường là một trong những bệnh nguy hiểm và đang trở thành vấn đề sức khỏe toàn cầu trong giai đoạn hiện nay. Người mắc bệnh đái tháo đường có hàm lượng đường glucose trong máu cao trong một thời gian dài (Alberti \& Zimmet, 1998). Bệnh đái tháo đường xảy ra khi tụy không sản xuất đủ insulin hoặc cơ thể giảm đáp ứng với tác dụng của insulin. Theo tổ chức y tế thế giới, số người mắc đái tháo đường từ năm 2008 đến năm 2014 tăng từ 108 đến 422 triệu (Roglic, 2016). Theo dự báo, năm 2030 bệnh đái tháo đường sẽ đứng đầu trong các bệnh gây tử vong trên thế giới. Việt Nam là một trong những nước có số người mắc đái tháo đường cao trong khu vực tây Thái Bình Dương với khoảng 3,5 triệu người trong năm 2015. Bệnh đái tháo đường gây ra nhiều biến chứng nguy hiểm như bệnh tim mạch vành, tai biến mạch máu não, mù mắt, suy thận và liệt dương. Theo thống kê, trên $90 \%$ bệnh nhân đái tháo đường thuộc type 2. Tăng đường huyết sau bữa ăn là vấn đề khó kiểm soát của đái tháo đường type 2 và cũng là mục tiêu chính của kiểm soát bệnh (Chatterjee \& ctv., 2017). Một trong các phương pháp để kiểm soát đường huyết sau bữa ăn là ức chế enzyme chuyển hóa carbohydrate như $\alpha$-amylase và $\alpha$-glucosidase. Bên cạnh một số loại thuốc ức chế enzyme $\alpha$-glucosidase dạng tổng hợp được sử dụng để điều trị đái tháo đường, gần đây nhiều nghiên cứu đã thực hiện để tìm kiếm các chất có nguồn gốc từ tự nhiên.

Vùng biển Khánh Hòa có cả ba ngành rong đỏ, rong lục và rong nâu. Trong đó, rong nâu là phổ biến nhất với nhiều loài có sản lượng thu hoạch lớn. Theo Titlyanov \& ctv. (2015), vịnh Nha Trang có 85 loài rong nâu. Rong nâu ở đây được đánh giá có hoạt tính sinh học như chống oxy hóa, kháng khuẩn, kháng tế bào ung thư 
và thu nhận một số thành phần có giá trị như alginate, fucoidan, phlorotannin (Cuong \& ctv., 2016). Tuy nhiên, đến nay nghiên cứu về hoạt tính ức chế enzyme $\alpha$-glucosidase của các loài rong nâu tại đây còn rất hạn chế.

Xuất phát từ những vấn đề trên, nghiên cứu này được thực hiện nhằm sàng lọc hoạt tính ức chế enzyme $\alpha$-glucosidase một số loài rong nâu thu hoạch tại vùng biển Khánh Hòa và xác định điều kiện chiết thích hợp cho loài rong tiềm năng.

\section{Vật Liệu và Phương Pháp Nghiên Cứu}

\subsection{Mẫu rong biển và hóa chất}

Nghiên cứu này sử dụng 7 loài rong nâu: Colpomenia sinuosa, Padina australis, Sargassum aquifolium, Sargassum mcclurei, Sargassum duplicatum, Sargassum polycystum, Sargassum swartzi. Mẫu rong nguyên liệu được thu hoạch trong khoảng thời gian từ tháng 4 đến tháng 7 năm 2017 tại các khu vực biển gần bờ: Sông Lô, Hòn Chồng, Bãi Tiên thuộc vịnh Nha Trang, tỉnh Khánh Hòa. Các mẫu rong được định danh bằng phương pháp hình thái học bởi ThS. Đỗ Anh Duy (Viện Nghiên cứu Hải sản, Hải Phòng).

Enzyme $\alpha$-glucosidase từ nấm men và cơ chất p-nitrophenyl- $\alpha$-D-glucopyranosid được cung cấp bởi công ty Sigma-Aldrich (Hoa Kỳ). Các dung môi methanol, n-hexan, ethyl acetate, butanol, DMSO được cung cấp bởi công ty Merck (Đức).

\subsection{Sàng lọc hoạt tính ức chế enzyme $\alpha$ - glucosidase của các loài rong nâu}

Kế thừa kết quả nghiên cứu trước đây (Kim \& ctv., 2008; Kim \& ctv., 2010), để sàng lọc hoạt tính ức chế enzyme $\alpha$-glucosidase các loài rong, quá trình chiết thực hiện như sau: $10 \mathrm{~g}$ rong khô được chiết trong 100\% methanol, tỷ lệ nguyên liệu/dung môi chiết (NL/DM) (w/v): 1/40, nhiệt độ chiết: $60^{\circ} \mathrm{C}$ và thời gian chiết: 60 phút. Sau quá trình chiết, hỗn hợp được lọc bằng giấy Whatman No.40. Dịch chiết được cô quay chân không ở nhiệt độ $\leq 60^{\circ} \mathrm{C}$ dể loại hết dung môi chiết và đánh giá khả năng ức chế enzyme $\alpha$-glucosidase.

\section{3. Ảnh hưởng của điều kiện chiết đến hoạt tính ức chế enzyme $\alpha$-glucosidase của rong Sargassum mcclurei}

Để nghiên cứu ảnh hưởng của tỷ lệ NL/DM chiết, các điều kiện chiết khác được giữ cố định bao gồm: dung môi chiết là 100\% methanol, thời gian chiết là 60 phút và nhiệt độ chiết là $60^{\circ} \mathrm{C}$. Các tỷ lệ NL/DM $(\mathrm{g} / \mathrm{mL})$ nghiên cứu gồm: 1/10, $1 / 20,1 / 30,1 / 40$ và $1 / 50$.

Để nghiên cứu ảnh hưởng của thời gian chiết, các điều kiện chiết khác được giữ cố định bao gồm: dung môi chiết $100 \%$ methanol, tỷ lệ $\mathrm{NL} / \mathrm{DM}$ được lựa chọn từ thí nghiệm trước và nhiệt độ chiết là $60^{\circ} \mathrm{C}$. Các thời gian chiết nghiên cứu gồm: $15,30,45,60,75$ và 90 phút.

Để nghiên cứu ảnh hưởng của nhiệt độ chiết, các điều kiện chiết khác được giữ cố định bao gồm: dung môi chiết $100 \%$ methanol, tỷ lệ $\mathrm{NL} / \mathrm{DM}$ và thời gian chiết được lựa chọn từ các thí nghiệm trước. Các nhiệt độ chiết nghiên cứu gồm: $30,40,50$ và $60^{\circ} \mathrm{C}$.

Trong tất cả các thí nghiệm về điều kiện chiết, 10 g rong khô được chiết với 100\% methanol ở các điều kiện chiết thí nghiệm. Sau quá trình chiết, hỗn hợp được lọc bằng giấy lọc Whatman No.40 để thu dịch chiết. Dịch chiết được cô quay chân không ở nhiệt độ $\leq 60^{\circ} \mathrm{C}$ dể loại hết dung môi chiết và đánh giá hoạt tính ức chế enzyme $\alpha$ glucosidase.

\subsection{Tách phân đoạn}

Rong khô (50 g) được chiết trong điều kiện chiết thích hợp đã được xác định. Tiếp theo, tiến hành loại dung môi của dịch chiết bằng thiết bị cô quay chân không. Dịch chiết sau khi loại hết dung môi methanol được tách phân đoạn sử dụng các dung môi có độ phân cực tăng dần bao gồm: n-hexane, ethyl acetate, butanol và nước. Dịch chiết sau khi đuổi dung môi được hòa vào $200 \mathrm{~mL}$ nước cất. Hỗn hợp sau đó đổ vào bình tách lỏnglỏng (separatory funnel). Tiếp theo, một lượng $200 \mathrm{~mL}$ dung môi $\mathrm{n}$-hexane được cho vào bình tách, lắc mạnh hỗn hợp dung môi trong thời gian 1 phút và để đứng yên trên giá đỡ trong khoảng thời gian 30 phút. Sau đó, thu phân đoạn dịch chiết n-hexane bằng cách mở van đáy của thiết bị tách lỏng-lỏng. Tiếp tục cho một lượng thể tích $200 \mathrm{~mL}$ vào bình tách lỏng - lỏng và lặp lại các thao tác như trên. Quá trình thu phân đoạn dung môi n-hexane được tiến hành đến khi quan sát phân đoạn dung môi này không màu. Phân đoạn dịch chiết n-hexane thu được bằng cách trộn lại sau các lần tách phân đoạn. Quá trình tách phân đoạn đối với dung môi ethyl acetate và butanol được tiến hành tương tự với n-hexane. Cuối cùng thu được các phân đoạn dung môi chiết: n- 
Bảng 1. Hoạt tính ức chế enzyme $\alpha$-glucosidase của một số loài rong nâu

\begin{tabular}{clc}
\hline STT & Loài rong & Khả năng ức chế enzyme $\alpha$-glucosidase $\left(\mathrm{IC}_{50}, \mu \mathrm{g} / \mathrm{mL}\right)^{*}$ \\
\hline 1 & Colpomenia sinuosa & $426,27 \pm 33,46^{\mathrm{d}}$ \\
2 & Padina australis & $361,64 \pm 12,95^{\mathrm{e}}$ \\
3 & Sargassum aquifolium & $314,09 \pm 5,82^{\mathrm{d}}$ \\
4 & Sargassum mcclurei & $154,27 \pm 7,49^{\mathrm{a}}$ \\
5 & Sargassumduplicatum & $190,20 \pm 2,89^{\mathrm{b}}$ \\
6 & Sargassum polycystum & $261,32 \pm 9,70^{\mathrm{c}}$ \\
7 & Sargassum swartzi & $278,85 \pm 5,92^{\mathrm{c}}$ \\
\hline a-e Các chữ cái khác nhau trong cùng một cồt chỉ ra sư khác nhau có ý nghĩa thống kê $(P<0,05)$.
\end{tabular}

${ }^{\text {a-e }}$ Các chữ cái khác nhau trong cùng một cột chỉ ra sự khác nhau có ý nghĩa thống kê $(P<0,05)$.

hexane, ethyl acetate, butanol và nước. Các phân đoạn dịch chiết được đuổi hết dung môi bằng thiết bị cô quay chân không. Phân đoạn dung môi thu được sau khi loại hết dung môi được xác định khả năng ức chế enzyme $\alpha$-glucosidase.

\section{5. Định tính một số thành phần trong dịch chiết}

Dịch chiết và phân đoạn ethyl acetate của rong Sargassum mcclurei được định tính một số nhóm chất bao gồm: phenolic, flavonoid, terpenoid, carotenoid, saponin và tannin. Trong mỗi thí nghiệm, cho 0,5 mL dịch chiết/phân đoạn dịch chiết vào ống nghiệm chứa $1,5 \mathrm{~mL}$ thuốc thử. Tiếp theo, quan sát màu của dung dịch để nhận biết các nhóm chất (Yadav \& ctv., 2014).

\subsection{Xác định hoạt tính ức chế enzyme}

Hoạt tính ức chế enzyme $\alpha$-glucosidase được xác định theo phương pháp của Kim \& ctv. (2008). Cho 0,1 mL mẫu (hòa tan trong dung môi dimethyl sulfoside - DMSO) vào hỗn hợp gồm $0,1 \mathrm{~mL}$ enzyme $(0,25 \mathrm{U} / \mathrm{mL})$ và $2,2 \mathrm{~mL}$ đệm phosphate $(0,01 \mathrm{M} ; \mathrm{pH} 7.0)$. Hỗn hợp được lắc đều và ủ ở $37^{\circ} \mathrm{C}$ trong 5 phút. Tiếp theo, 0,1 $\mathrm{mL}$ dung dịch cơ chất chất p-nitrophenyl- $\alpha$-Dglucopyranosid $(3 \mathrm{mM})$ được thêm vào hỗn hợp để thực hiện quá trình phản ứng. Hỗn hợp được giữ ở nhiệt độ $37^{\circ} \mathrm{C}$ trong 30 phút. Để kết thúc phản ứng, cho $1,5 \mathrm{~mL}$ dung dịch $\mathrm{Na}_{2} \mathrm{CO}_{3}(0,1$ $\mathrm{M})$ vào hỗn hợp và đo độ hấp thụ quang học ở bước sóng $405 \mathrm{~nm}$. Hoạt tính ức chế enzyme $\alpha$ glucosidase được tính theo công thức:

Hoạt tính ức chế enzyme $\alpha$-glucosidase (\%) = $\left[\left(\mathrm{A}_{0}-\mathrm{A}_{1}\right) / \mathrm{A}_{0}\right] \times 100$; trong đó:

$\mathrm{A}_{1}$ : Độ hấp thụ quang của mẫu thí nghiệm.

$\mathrm{A}_{0}$ : Độ hấp thụ quang của mẫu trắng.

Giá trị $\quad \mathrm{IC}_{50}(\mu \mathrm{g} / \mathrm{mL})$ là nồng độ dịch chiết/phân đoạn dịch chiết cho hoạt tính ức chế $50 \%$ (giá trị $\mathrm{IC}_{50}$ càng thấp, hoạt tính ức chế enzyme càng cao).

\subsection{Phương pháp xử lý số liệu}

Tất cả các thí nghiệm được thực hiện 3 lần độc lập. Kết quả của thí nghiệm được biểu diễn bằng giá trị trung bình \pm độ lệch chuẩn. Giá trị trung bình được phân tích ANOVA theo phép thử Ducan, giá trị $P<0,05$ chỉ ra sự khác nhau có ý nghĩa thống kê sử dụng phần mềm SPSS phiên bản 16,0 .

\section{Kết Quả và Thảo Luận}

\subsection{Khả năng ức chế enzyme $\alpha$-glucosidase của một số loài rong nâu}

Kết quả nghiên cứu hoạt tính ức chế enzyme $\alpha$-glucosidase của các loài rong nghiên cứu được thể hiện ở Bảng 1. Tất cả 7 loài rong nâu sử dụng đều có hoạt tính ức chế enzyme $\alpha$ glucosidase, với giá trị $\mathrm{IC}_{50}$ của Colpomenia sinuosa, Padina australis, Sargassum aquifolium, Sargassum mcclurei, Sargassum duplicatum, Sargassum polycystum và Sargassum swartzi lần lượt là 426,$27 ; 361,64 ; 314,09 ; 154,27 ; 190,20 ; 261,32$ và $278,85 \mu \mathrm{g} / \mathrm{mL}$. Như vậy, loài rong Sargassum mcclurei có hoạt tính ức chế enzyme $\alpha$-glucosidase mạnh nhất trong các loài rong nghiên cứu. Theo Nguyen \& ctv. (2018), giá trị $\mathrm{IC}_{50}$ của 3 loài rong nâu Turbinaria ornate, Sargassum oligocystem và Sargassum microcystem thu mẫu tại vùng biển Khánh Hòa dao động từ 530 đến $2.890 \mu \mathrm{g} / \mathrm{mL}$. Như vậy, các loài rong nâu thu hoạch tại vùng biển Khánh Hòa có hoạt tính ức chế enzyme $\alpha$ glucosidase khác nhau đáng kể. Sự khác nhau về hoạt tính của các loài rong có thể do thành phần và hàm lượng các chất có hoạt tính sinh học. Sự khác nhau còn có thể do thời điểm thu hoạch, 


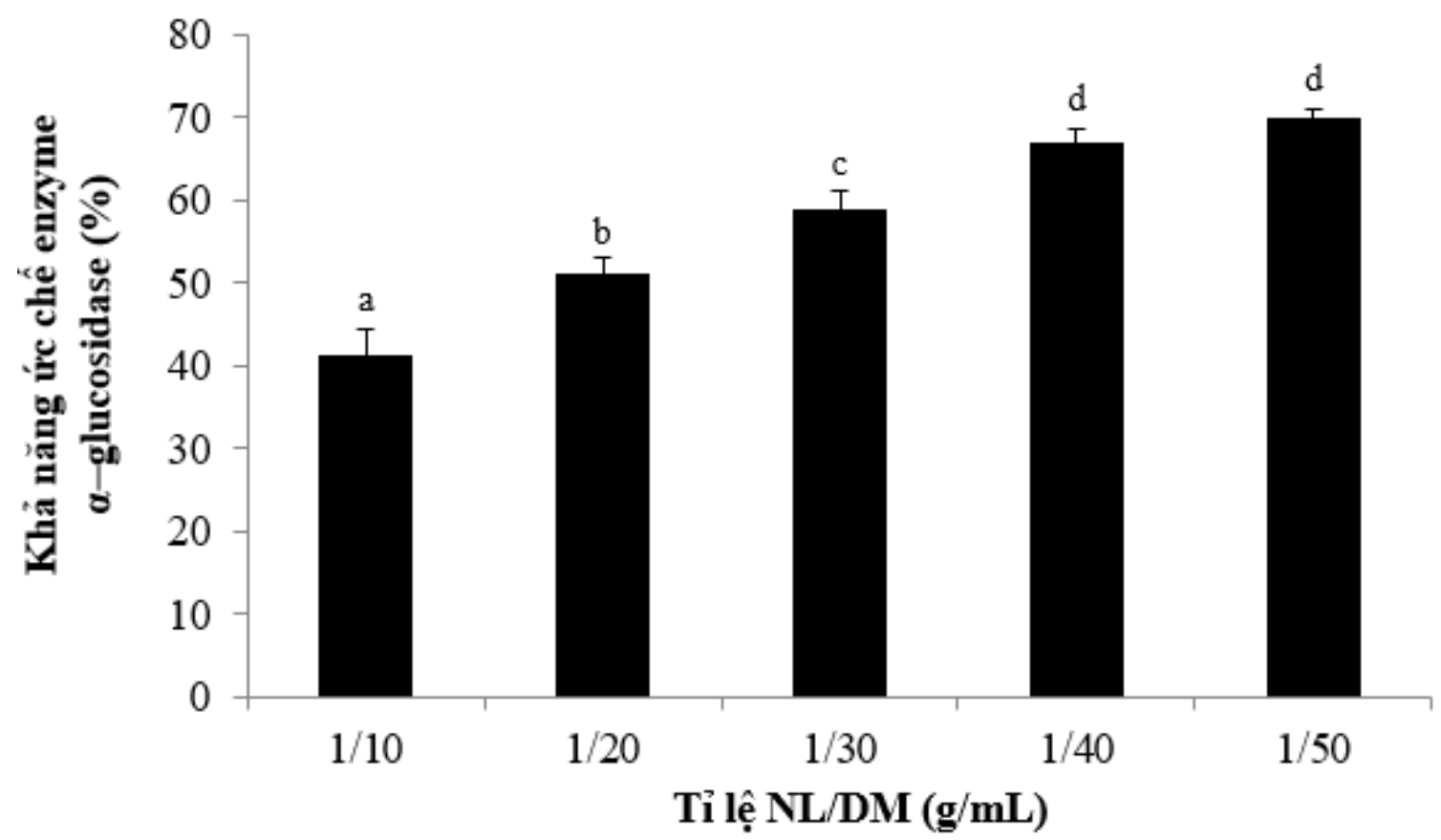

Hình 1. Ảnh hưởng của tỷ lệ NL/DM $(\mathrm{g} / \mathrm{mL})$ đến hoạt tính ức chế enzyme $\alpha$-glucosidase của dịch chiết từ rong Sargassum mcclurei. Các chữ cái khác nhau chỉ ra sự khác nhau có ý nghĩa thống kê $(P<0,05)$.

phương pháp thu hoạch, xử lý và bảo quản mẫu rong. Dựa vào kết quả nghiên cứu, loài rong Sargassum mcclurei được lựa chọn để thực hiện các nghiên cứu tiếp theo.

\section{2. Ảnh hưởng của điều kiện chiết đến hoạt tính ức chế enzyme $\alpha$-glucosidase của rong Sargassum mcclurei}

\subsection{1. Ảnh hưởng của tỷ lệ nguyên liệu/dung môi}

Kết quả nghiên cứu ảnh hưởng của tỷ lệ NL/DM đến khả năng ức chế enzyme $\alpha$ glucosidase của rong Sargassum mcclurei được thể hiện ở Hình 1. Hoạt tính ức chế enzyme tăng theo chiều giảm của tỷ lệ NL/DM trong khoảng từ $1 / 10$ đến $1 / 40(\mathrm{~g} / \mathrm{mL})$. Khi tiếp tục tăng tỷ lệ lên $1 / 50(\mathrm{~g} / \mathrm{mL})$ thì hoạt tính ức chế enzyme không tiếp tục tăng. Cụ thể, dịch chiết được thu nhận ở tỷ lệ NL/DM $1 / 10,1 / 20,1 / 30,1 / 40$ và $1 / 50$ lần lượt là $41,33 \% ; 51,12 \% ; 58,94 \% ; 67,03 \%$ và $69,81 \%$. Kết quả này phù hợp với lý thuyết của quá trình chiết. Khi tỷ lệ NL/DM tăng đến một giới hạn nhất định, quá trình chiết sẽ bão hòa, hiệu quả chiết các chất có hoạt tính sinh học sẽ không tiếp tục tăng. Ngoài ra, sử dụng lượng lớn dung môi có thể dẫn tới thời gian lọc sau quá trình chiết kéo dài, có thể dẫn đến biến tính các chất có hoạt tính sinh học và làm giảm hoạt tính. Việc sử dụng nhiều dung môi cũng gây lãng phí và gánh nặng hơn đối với môi trường. Như vậy, tỷ lệ $\mathrm{NL} / \mathrm{DM}$ là $1 / 40(\mathrm{~g} / \mathrm{mL})$ được xác định là tỷ lệ thích hợp để chiết các chất có hoạt tính ức chế enzyme $\alpha$-glucosidase từ rong Sargassum mcclurei.

\subsection{2. Ảnh hưởng của thời gian chiết}

Kết quả nghiên cứu ảnh hưởng của thời gian chiết đến hoạt tính ức chế enzyme $\alpha$-glucosidase của rong Sargassum mcclurei được thể hiện ở Hình 2. Hoạt tính ức chế enzyme tăng dần theo thời gian chiết từ 15 phút dến 60 phút. Cụ thể, khi thời gian chiết là 15 phút thì khả năng ức chế là 19,47\%; khi tăng thời gian chiết lên 30 phút thì khả năng ức chế enzyme tăng lên $27,11 \%$ và đạt lần lượt 41,24 và 51,38\% khi thời gian là 45 và 60 phút. Tuy nhiên, khi tiếp tục tăng thời gian chiết lên 75 phút thì hoạt tính ức chế enzyme $\alpha$-glucosidase của dịch chiết rong Sargassum mcclurei không tiếp tục tăng $(P>0,05)$ và có xu hướng giảm khi tăng thời gian chiết lên 90 phút. Kết quả này phù hợp với một số nghiên 


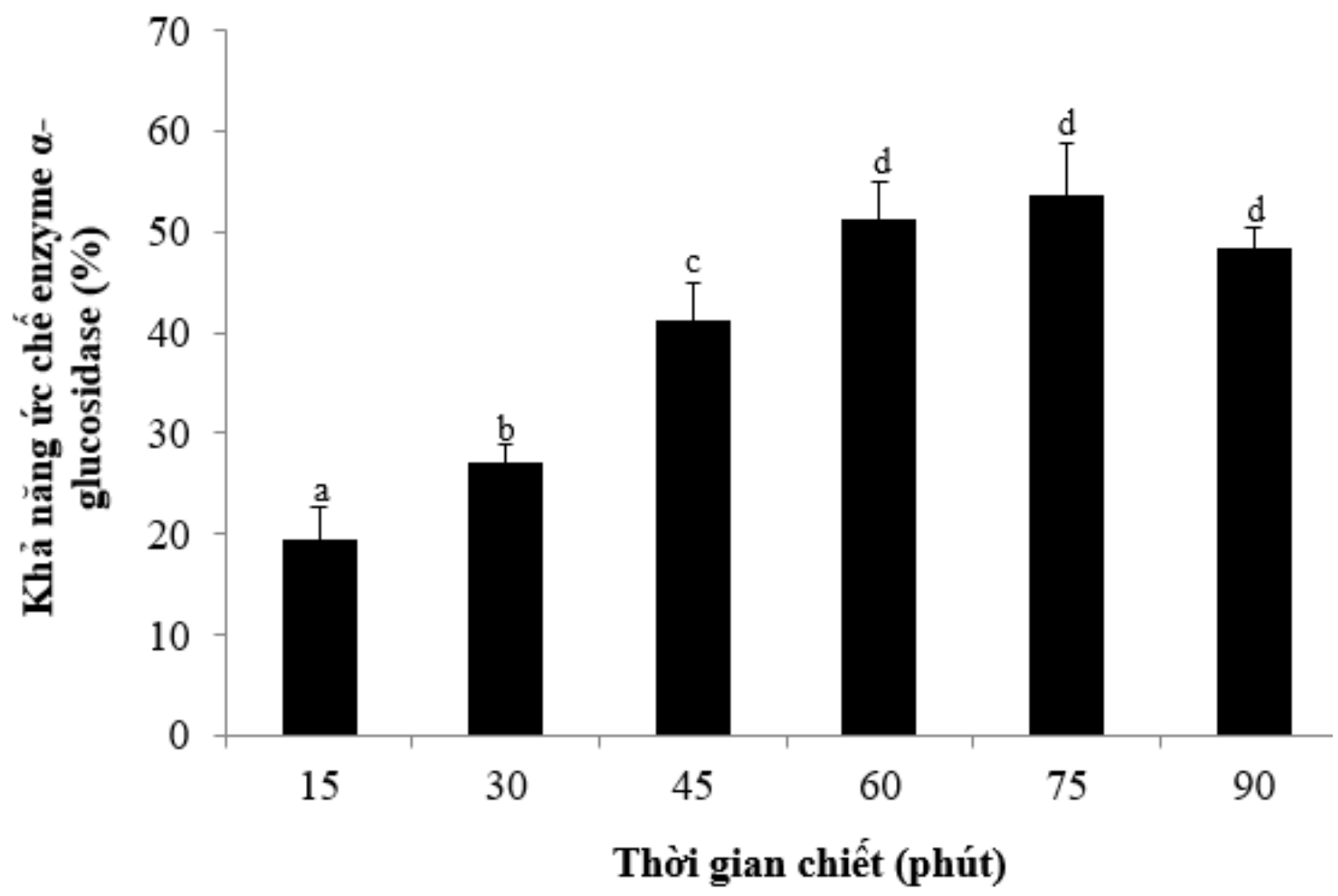

Hình 2. Ảnh hưởng của thời gian chiết đến hoạt tính ức chế enzyme $\alpha$-glucosidase của dịch chiết từ rong Sargassum mcclurei. Các chữ cái khác nhau chỉ ra sự khác nhau có ý nghĩa thống kê $(P<0,05)$.

cứu trên các đối tượng tương tự. Theo Nguyen \& ctv. (2018), hoạt tính ức chế của enzyme $\alpha$ glucosidase của rong nâu Turbinaria ornate tăng dần theo chiều tăng của thời gian chiết từ 15 dến 75 phút và giảm khi tiếp tục tăng thời gian chiết lên 90 phút. Như vậy, một số chất có hoạt tính ức chế enzyme $\alpha$-glucosidase có trong rong Sargassum mcclurei có thể không bền ở điều kiện nhiệt độ cao. Một số nghiên cứu chỉ ra rằng polyphenol là chất ức chế enzyme $\alpha$-glucosidase phổ biến trong rong biển. Các hợp chất polyphenol có hoạt tính ức chế $\alpha$-glucosidase trong một số loài rong nâu đã được chứng minh là không bền ở nhiệt độ chiết cao (Yuan \& ctv., 2018). Dựa vào kết quả nghiên cứu, 60 phút được lựa chọn là thời gian thích hợp để chiết các chất có hoạt tính ức chế enzyme $\alpha$-glucosidase từ rong Sargassum mcclurei.

\subsection{3. Ảnh hưởng của nhiệt độ chiết}

Ảnh hưởng của nhiệt độ chiết đến hoạt tính ức chế enzyme $\alpha$-glucosidase của dịch chiết rong
Sargassum mcclurei được thể hiện ở Hình 3. Hoạt tính ức chế enzyme $\alpha$-glucosidase tăng theo chiều tăng của nhiệt độ chiết từ 30 đến $60^{\circ} \mathrm{C}$; hoạt tính ức chế của dịch chiết ở nhiệt độ $30,40,50$ và $60^{\circ} \mathrm{C}$ lần lượt là 35,$24 ; 45,62 ; 50,29$ và $56,95 \%$. Như vậy, trong phạm vi nghiên cứu, $60^{\circ} \mathrm{C}$ là nhiệt độ thích hợp để thu nhận dịch chiết có hoạt tính ức chế enzyme $\alpha$-glucosidase cao nhất. Sự ảnh hưởng của nhiệt độ chiết đến hoạt tính sinh học từ nguyên liệu tự nhiên phụ thuộc vào đặc tính của chất cần chiết, đặc điểm của nguyên liệu và phương pháp chiết sử dụng. Nhiệt độ thích hợp để thu nhận dịch chiết có hoạt tính ức chế enzyme $\alpha$ glucosidase cao từ rong biển rất khác nhau theo loài rong. Theo Catarino \& ctv. (2019), hoạt tính ức chế enzyme $\alpha$-glucosidase của dịch chiết từ rong nâu Fucus vesiculosus cao hơn khi chiết ở nhiệt độ thấp (từ 17 đến $25^{\circ} \mathrm{C}$ ) so với nhiệt độ cao (từ 37 và $50^{\circ} \mathrm{C}$ ). Nhiệt dộ chiết thích hợp nhất để thu nhận dịch chiết có hoạt tính ức chế enzyme $\alpha$-glucosidase từ loài rong này là $20^{\circ} \mathrm{C}$.

Theo các kết quả thí nghiệm ở trên có thể nhận thấy, trong cùng một điều kiện chiết cho 


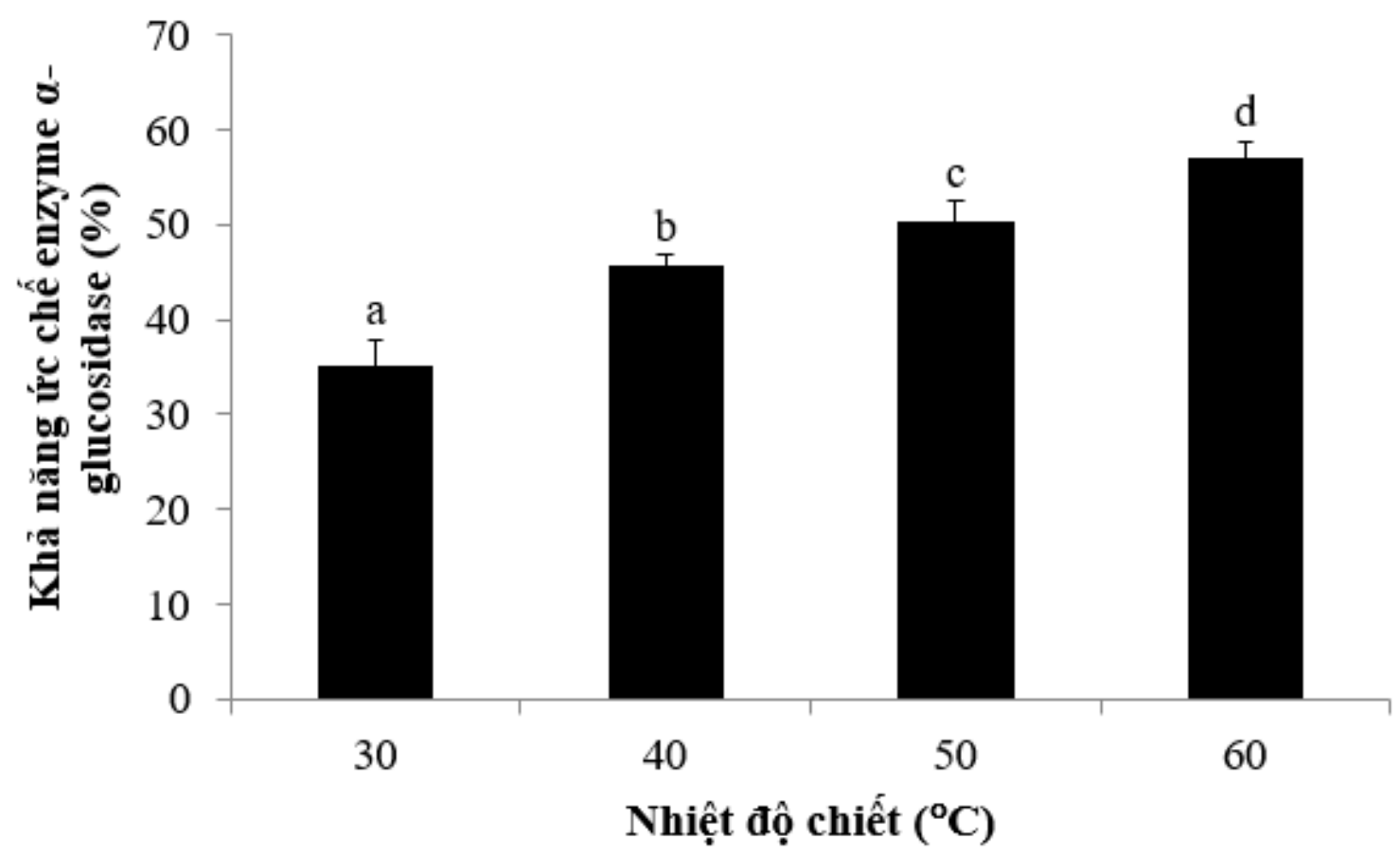

Hình 3. Ảnh hưởng của nhiệt độ chiết đến hoạt tính ức chế enzyme $\alpha$-glucosidase của dịch chiết từ rong Sargassum mcclurei. Các chữ cái khác nhau chỉ ra sự khác nhau có ý nghĩa thống kê $(P<0,05)$.

kết quả không đồng nhất. Ví dụ, dịch chiết thu nhận ở điều kiện chiết như nhau (dung môi chiết: methanol, tỉ lệ NL/DM: $1 / 40(\mathrm{~g} / \mathrm{mL})$, thời gian: 60 phút, nhiệt độ: $60^{\circ} \mathrm{C}$ ) nhưng cho hoạt tính ức chế enzyme khác nhau. Cụ thể, hoạt tính ức chế enzyme $\alpha$-glucosidase của dịch chiết ở Hình 1 (ảnh hưởng của tỷ lệ NL/DM) là 67,03\%; trong khi đó, ở Hình 2 (ảnh hưởng của thời gian chiết) là $51,38 \%$ và ở Hình 3 (ảnh hưởng của nhiệt độ chiết) là 56,95\%. Sự khác nhau về kết quả thí nghiệm có thể là do các mẫu rong sử dụng trong các nghiên cứu không đồng nhất về tính chất vật lý và thành phần hóa học. Do đó, nghiên cứu tiếp theo cần đảm bảo được tính đồng nhất của nguyên liệu rong khi đánh giá ảnh hưởng của điều kiện chiết.

3.3. Hoạt tính ức chế enzyme $\alpha$-glucosidase của các phân đoạn dịch chiết từ rong Sargassum mcclurei

Các hợp chất có hoạt tính sinh học trong rong biển có độ phân cực và khả năng hòa tan khác nhau. Trong nghiên cứu này, các dung môi có độ phân cực tăng dần (n-hexane, ethyl acetate, bu- tanol và nước) được sử dụng để tách chiết các chất có hoạt tính ức chế enzyme $\alpha$-glucosidase từ rong Sargassum mcclurei (Hình 4). Hoạt tính ức chế enzyme $\alpha$-glucosidase của phân đoạn ethyl acetate cao nhất, tiếp theo là phân đoạn butanol, n-hexane và nước. Cụ thể, ở nồng độ $300 \mu \mathrm{g} / \mathrm{mL}$, phân đoạn ethyl acetate, butanol, n-hexane và nước ức chế enzyme $\alpha$-glucosidase lần lượt là 83,$63 ; 38,79 ; 26,12$ và $16,57 \%$. Giá trị $\mathrm{IC}_{50}$ của các phân đoạn dung môi ethyl acetate, butanol, n-hexane và nước lần lươt là 35,$76 ; 384,97 ; 568,58$ và $863,69 \mu \mathrm{g} / \mathrm{mL}$.

Phân đoạn dung môi chiết ethyl acetate thường được sử dụng để tách chiết sơ bộ các chất có hoạt tính sinh học từ nguyên liệu tự nhiên. Phân đoạn ethyl acetate từ năm loài rong nâu thu hoạch tại vùng biển của Indonesia có hoạt tính ức chế enzyme $\alpha$-glucosidase cao hơn phân đoạn dung môi chiết còn lại (ethanol, n-hexane và nước) (Firdaus \& Prihanto, 2014). Phân đoạn ethyl acetate từ dịch chiết rong nâu Fucus vesiculosus có hoạt tính ức chế enzyme $\alpha$-glucosidase mạnh hơn nhiều so với các phân đoạn còn lại (n-hexane và nước) (Kim \& ctv., 2008; Catarino \& ctv., 2019). Phân đoạn ethyl acetate của rong Sargassum mcclurei 


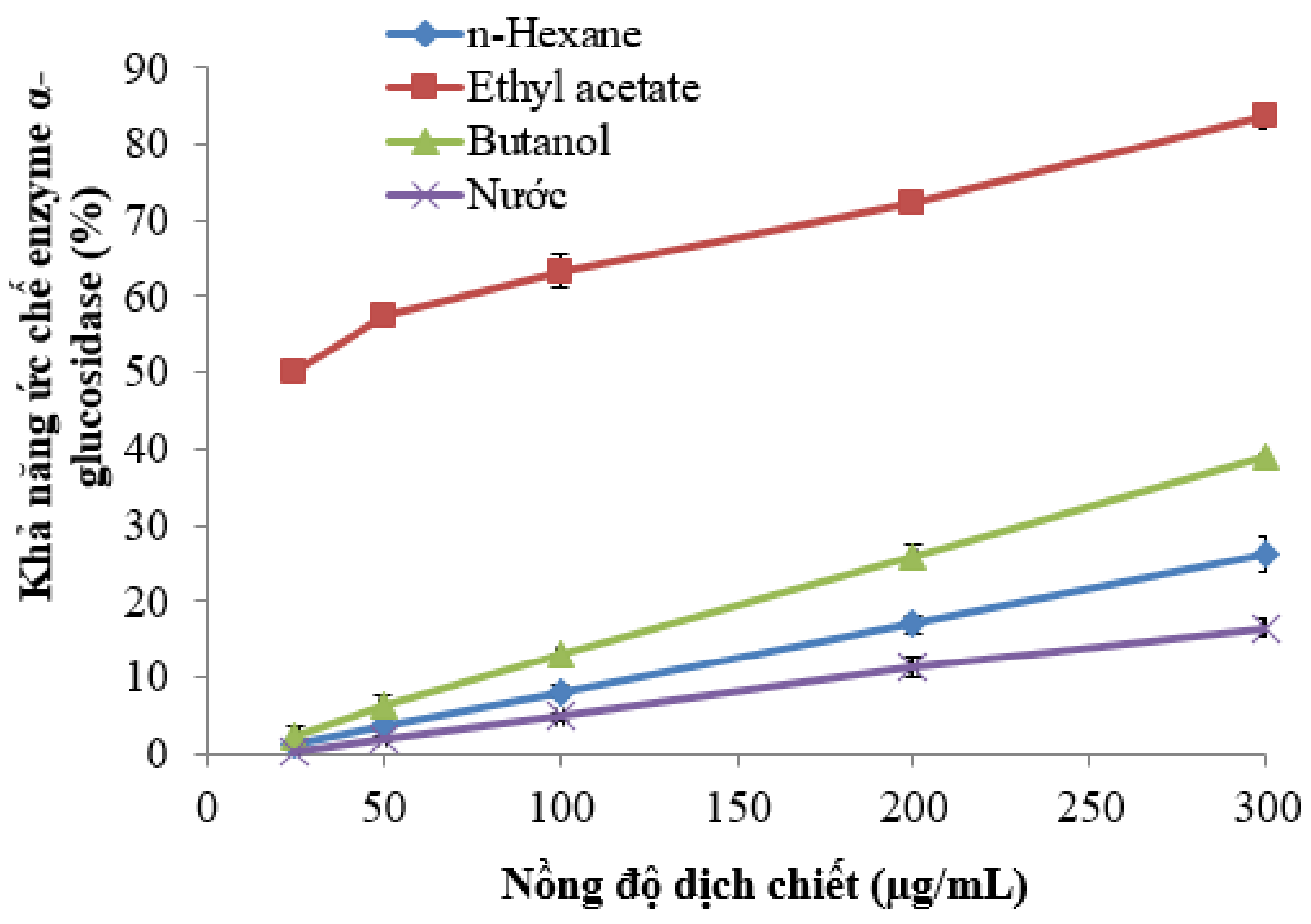

Hình 4. Hoạt tính ức chế enzyme $\alpha$-glucosidase của các phân đoạn dung môi chiết từ rong Sargassum mcclurei.

cho hoạt tính ức chế enzyme $\alpha$-glucosidase cao nhất, cho thấy nhóm chất chính có hoạt tính ức chế enzyme $\alpha$-glucosidase thuộc nhóm chất có độ phân cực thấp và trung bình như polyphenol, phlorotannin và flavonoid.

\subsection{Nhận biết một số nhóm chất có trong dịch chiết rong Sargassum mcclurei}

Kết quả định tính một số thành phần phổ biến có trong dịch chiết và phân đoạn dịch chiết từ rong nâu Sargassum mcclurei được thể hiện ở Bảng 2. Dịch chiết rong Sargassum mcclurei có chứa tất cả các thành phân nghiên cứu: alkaloid, phenolic, flavonoid, carotenoid, terpenoid, saponin và tannin. Trong khi đó, phân đoạn ethyl acetate chỉ có sự xuất hiện của bốn nhóm chất: phenolic, flavonoid, terpenoid và tannin. Kết quả nghiên cứu này phù hợp với một số nghiên cứ trước đây trên các đối tượng rong nâu. Thành phần các nhóm chất có trong rong biển phụ thuộc vào điều kiện tách chiết và tác động bởi các yếu tố môi trường sống của rong. Nghiên cứu một số thành phần có trong ba loài rong Sargassum angustifolium, Sargassum oligocystum và Sargassum boveanum thu hoạch tại vùng biển của Ấn Độ, cho thấy cả ba loài rong đều có tannin, alkaloid, saponin, flavonoid (Mehdinezhad \& ctv., 2016). Các nhóm chất phenolic, flavonoid, terpenoid và tannin trong phân đoạn dịch chiết ethyl acetate đã được chứng minh là những thành phần có hoạt tính ức chế enzyme $\alpha$-glucosidase trong rong biển (Kim \& ctv., 2008; Firdaus \& Prihanto, 2014).

\section{Kết Luận}

Tất cả 7 loài rong nâu thu hoạch tại vùng biển Khánh Hòa đều có khả năng ức chế enzyme $\alpha$-glucosidase; trong đó, Sargassum mcclurei có hoạt tính ức chế enzyme cao nhất. Nghiên cứu đã xác định được điều kiện chiết thích hợp cho rong Sargassum mcclurei. Phân đoạn ethyl acetate có hoạt tính ức chế enzyme $\alpha$-glucosidase cao nhất trong các phân dung môi nghiên cứu. 
Bảng 2. Định tính một số nhóm chất có trong dịch chiết và phân đoạn dịch chiết từ rong Sargassum mcclurei

\begin{tabular}{ccc}
\hline $\begin{array}{c}\text { Nhóm } \\
\text { chất }\end{array}$ & $\begin{array}{c}\text { Dịch chiết } \\
\text { methanol }\end{array}$ & $\begin{array}{c}\text { Phân đoạn } \\
\text { ethyl acetate }\end{array}$ \\
\hline Alkaloid & $+^{*}$ & $-* *$ \\
Phenolic & + & + \\
Flavonoid & + & + \\
Terpenoid & + & + \\
Carotenoid & + & - \\
Tannin & + & + \\
Saponin & + & - \\
\hline *++": Có xuất hiện; **“-": Không xuất hiện.
\end{tabular}

Một số nhóm chất chính trong phân đoạn này bao gồm: phenolic, flavonoid, terpenoid và tannin. Nghiên cứu tiếp theo cần tinh sạch các hợp chất có hoạt tính ức chế enzyme $\alpha$-glucosidase từ rong Sargassum mcclurei và thử nghiệm hoạt tính kháng đái tháo đường của loài rong này trên mô hình in vivo.

\section{Lời Cảm Ơn}

Nghiên cứu này được tài trợ bởi Quỹ Phát triển khoa học và công nghệ Quốc gia (NAFOSTED) trong đề tài mã số 106-NN.05- 2016.73.

\section{Tài Liệu Tham Khảo (References)}

Alberti, K. G. M. M., \& Zimmet, P. Z. (1998). Definition, diagnosis and classification of diabetes mellitus and its complications. Part 1: diagnosis and classification of diabetes mellitus. Provisional report of a WHO consultation. Diabetic Medicine 15(7), 539-553.

Catarino, M. D., Silva, A., Mateus, N., \& Cardoso, S. M. (2019). Optimization of phlorotannins extraction from fucus vesiculosus and evaluation of their potential to prevent metabolic disorders. Marine Drugs 17(3), 162.

Chatterjee, S., Khunti, K., \& Davies, M. J. (2017). Type 2 diabetes. The Lancet 389(10085), 2239-2251.
Cuong, D. X., Boi, V. N., \& Van, T. T. T. (2016). Effect of storage time on phlorotannin content and antioxidant activity of six Sargassum species from Nhatrang Bay, Vietnam. Journal of Applied Phycology 28(1), 567-572.

Firdaus, M., \& Prihanto, A. A. (2014). $\alpha$-Amylase and $\alpha$ glucosidase inhibition by brown seaweed (Sargassum sp) extracts. Research Journal of Life Science 1(1), 06-11.

Kim, K. Y., Nam, K. A., Kurihara, H., \& Kim, S. M. (2008). Potent $\alpha$-glucosidase inhibitors purified from the red alga Grateloupia elliptica. Phytochemistry 69(16), 2820-2825.

Kim, K. Y., Nguyen, T. H., Kurihara, H., \& Kim, S. M. (2010). $\alpha$-Glucosidase inhibitory activity of bromophenol purified from the red alga Polyopes lancifolia. Journal of Food Science 75(5), 145-150.

Mehdinezhad, N., Ghannadi, A., \& Yegdaneh, A. (2016). Phytochemical and biological evaluation of some Sargassum species from Persian Gulf. Research in Pharmaceutical Sciences 11(3), 243-249.

Nguyen, T. H., Nguyen, T. K. N., \& Nguyen, V. M. (2018). Evaluation of $\alpha$-glucosidase inhibitory activity of some selected seaweed extracts. Journal of Fisheries Science and Technology 1, 24-33.

Roglic, G. (2016). WHO global report on diabetes: A summary. International Journal of Noncommunicable Diseases 1(1), 3-8.

Titlyanov, E. A., Titlyanova, T. V., \& Belous, O. S. (2015). Checklist of the marine flora of Nha Trang Bay (Vietnam, South China Sea) and decadal changes in the species diversity composition between 1953 and 2010. Botanica Marina 58(5), 367-377.

Yadav, M., Chatterji, S., Gupta, S. K., \& Watal, G. (2014). Preliminary phytochemical screening of six medicinal plants used in traditional medicine. International Journal of Pharmacy and Pharmaceutical Sciences 6(5), 539-542.

Yuan, Y., Zhang, J., Fan, J., Clark, J., Shen, P., Li, Y., \& Zhang, C. (2018). Microwave assisted extraction of phenolic compounds from four economic brown macroalgae species and evaluation of their antioxidant activities and inhibitory effects on $\alpha$-amylase, $\alpha$ glucosidase, pancreatic lipase and tyrosinase. Food Research International 113, 288-297. 